\title{
Our experiences in medical photography at the burn center
}

\section{Yanık merkezindeki tıbbi fotoğrafçılık tecrübelerimiz}

\author{
Yucel Yuce ${ }^{1 *} \mathbb{D}$, Kutlu Hakan Erkal ${ }^{1}$ (D), Oguzhan Kılavuz ${ }^{1}$ \\ ${ }^{1}$ Kartal Dr. Lutfi Kirdar Education and Research Hospital, Anaesthesiology and Reanimation Department, Kartal, Istanbul, Turkey \\ * Corresponding author: Yucel Yuce E-mail: dryyuce@gmail.com ORCID: 0000-0003-0396-1248 \\ Received: 21 December 2017 Accepted: 27 March 2018
}

\begin{abstract}
Introduction: Medical photography has a wide range of uses. Photographs are used in clinical documentation, in publishing research in scientific journals, and in teaching.

Material and Method: We evaluated the pictures of patients treated with 2009-2017 in intensive care unit, service and outpatient departments of the Burn Center of Kartal Dr. Lutfi Kirdar Education and Research Hospital.

Findings: At the dates mentioned, the photographs of a total of 13150 patients ( 1162 burn intensive care patients, 3583 burn patients in regular service and 8405 outpatients) were taken. Each step of the patient's treatments was photographed and archived digitally. We pictured the latest changes in dressing, urine color, and non-common diseases. We recorded the areas and donor sites where grafts are applied during surgical procedures and the most recent statuses digitally.

Discussion: Photography has become part of the treatment of burn patients. Calculation of burn fractions, evaluation of damage at the time of first application, identification of areas to be infected or grafting is possible by photographing. Also; detection of causes of graft loss wound healing and sequelae formation can also be done with this photograph. Also, they provide evidence of applied treatments and materials used. We believe that digital imaging is an easy and inexpensive method of recording burned patients' images in countries where laser Doppler imaging and psychoacoustical imaging are expensive.
\end{abstract}

Keywords: burns, medical photography, intensive care

() 2019 by the authors; licensee MEDITAGEM Ltd., Turkey. This article is an open access article distributed under the terms and conditions of the Creative Commons Attribution License (http://creativecommons.org/licenses/by/4.0/). 


\section{öz}

Giriş: Tıbbi fotoğrafçılı̆̆ın çok geniş bir kullanım alanı vardır. Fotoğraflar klinik dokümantasyonda, bilimsel dergilerde araştırmaların yayımlanmasında ve öğretim alanında kullanılırlar.

Materyal ve Metod: Kartal Dr. Lütfi Kırdar Eğitim ve Araştırma Hastanesi Yanık Merkezi'nde 2009-2017 yılları arasında tedavi edilen yoğun bakım, servis ve poliklinik hastasının çekilen resimleri değerlendirilmiştir.

Bulgular: Belirtilen tarihlerde toplam 11866 hastanın (841 yanık yoğun bakım hastası, 2613 yanık servis hastası ve 8405 poliklinik hastası) tedavilerinin her basamağında çekilen resimleri toplanmıştır. Hastaların tedavilerinin her basamağını fotoğraflandı ve dijital ortamda arşivlendi. Pansuman değişimlerinin son halleri, idrar rengi ve yaygın olmayan hastalıklar fotoğraflandı. Cerrahi işlemler sırasında greft uygulanan alanlar ve donör alanları; son durumları dijital olarak kaydedildi.

Tartışma: Fotoğraflama yanık hastalarının tedavilerinin bir parçası haline gelmiştir. Yanık yüzdelerinin hesaplanması, ilk başvuru anında hasarların değerlendirilmesi, enfekte alanların ya da greft uygulanacak alanların belirlenmesi fotoğraflama ile mümkündür. Ayrıca; greft kaybının nedenlerinin tespiti, yara iyileşmesinin ve sekel oluşumunun takibi de bu fotoğraflama ile yapılabilir. Ek olarak uygulanan tedavilere ve kullanılan materyallere kanıt oluştururlar. Ayrıca lazer doppler görüntüleme ve fotoakustik görüntüleme gibi cihazların pahalı olarak değerlendirildiği ülkelerde dijital fotoğrafçılığın yanık hastalarının görüntülerinin kaydedilmesinde kolay ve ucuz bir yöntem olduğunu düşünmekteyiz.

Anahtar kelimeler: yanık, tıbbi fotoğrafçılık, yoğun bakım

\section{INTRODUCTION}

During history, documentation of the medical information and procedures was essential for humans. The invention of the cameras two hundred years ago facilitated this procedure. In 1895 Wilhelm Conrad Roentgen obtained the first medical image by using $x$ rays [1]. Usage of these two techniques developed a new era called as medical photography. Medical photography has a grand scale of usage involving pictures in medical books, ophthalmic angiographic images, recordings before plastic surgery operations and forensic medicine recordings.

In the latest years, development of modern techniques of recording and saving made medical photography a vital profession [2]. The practice requires a high level of technical skill to present the photograph free from misleading information that may cause misinterpretation. The medical pictures are used in clinical documentation, research, treatment planning, publication in scientific journals and teaching [3]. These photographs were first widely used in books particularly in the areas of dermatology and plastic and reconstructive surgeries, where the inclusion of photographic images is recognized to enhance the descriptions of diagnoses and complex procedures [4].

We realized that the written documentation for burn patients was not enough. We were both marking the Lund-

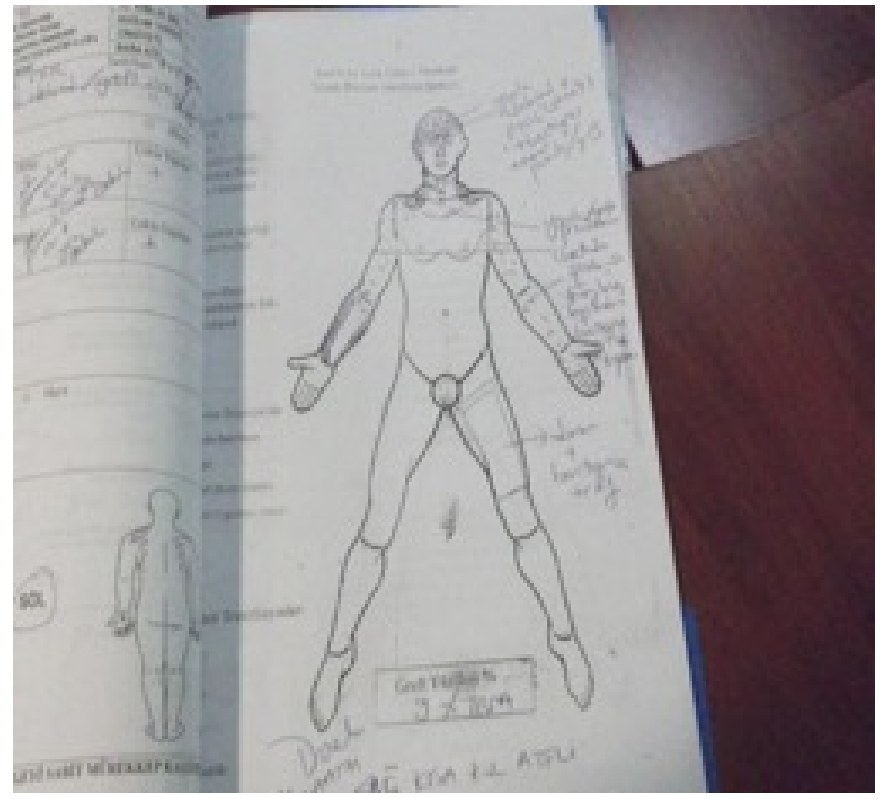

Figure 1. Lund- Brower chart

Brower charts and drawing burn areas on operation forms which also helped to calculate the burn area (Figure 1). However, the burn wounds were different at every dressing change or operation. Therefore, we decided to photograph every step of the treatment of our in and outpatients and store these in digital media.

The purpose of this study was to assess our experience in medical photography and to propose standards for medical 


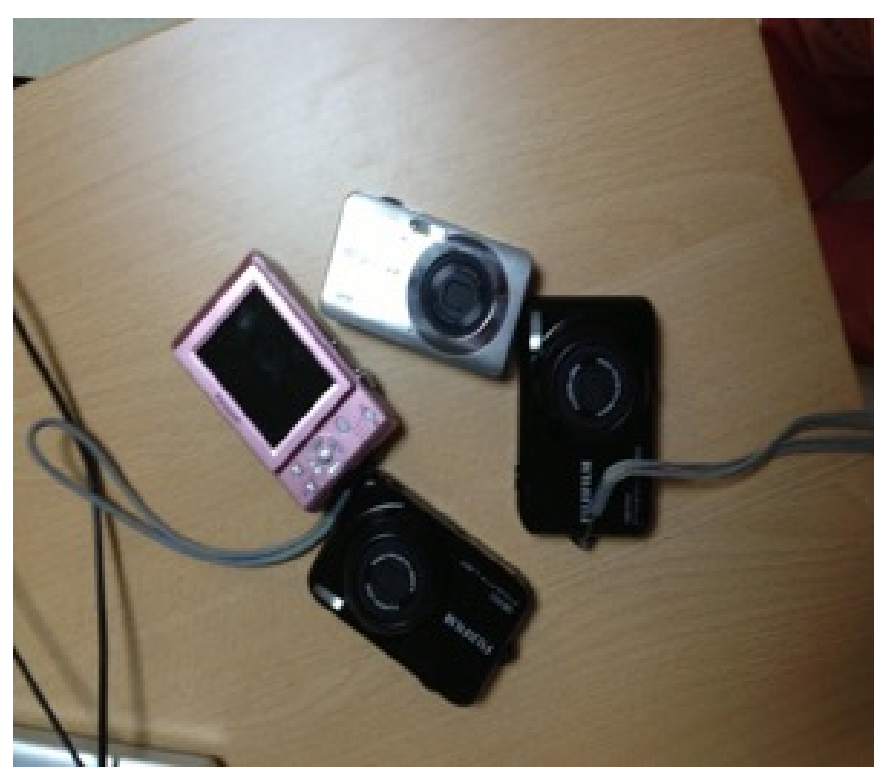

Figure 2. Digital cameras for recording

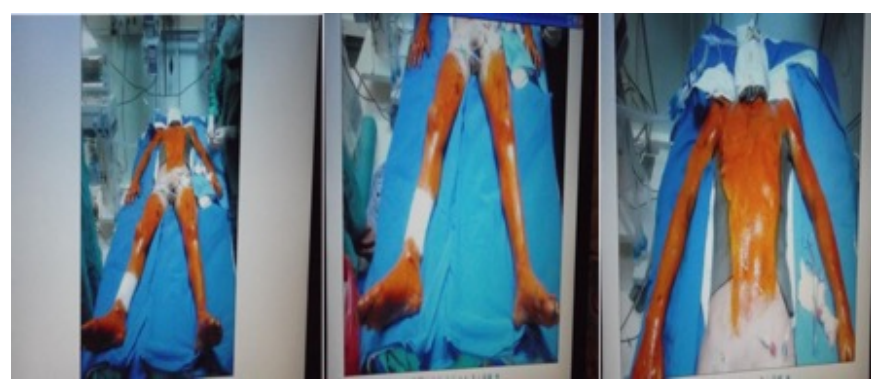

Figure 3. A sample of photo recording of a patient

photography in a burn center. We also aimed to guide the work to be done by future burn centers.

\section{MATERIAL AND METHOD}

The Kartal Dr. Lutfi Kirdar Education and Research Hospital Burn Unit was the most significant and best-equipped burn center in Turkey. It has six intensive care unit beds, 16 burn service beds, and two separate operating rooms, all housed in one building. In this center a multidisciplinary crew working due to American Burn Association criteria consisting of general surgeons, plastic surgeons, anesthetists either in intensive care unit or operating rooms, infectious disease doctors, pediatric surgeons, physiotherapists, psychologists, dieticians and burn nurses.

We started to take consent for imaging as we took informed consents. Five cameras were at the head nurse of outpatient department, head nurse of burn bath/wound care department, head nurse of intensive care unit, head nurse of operation room and the chief doctor. The final condition of the dressing change, urine color, and the rare diseases were essential issues which we took their photographs. During the operation, the grafted areas and the donor sites and when areas like hand and face are grafted, the photographic recording of them was so vital for us. The final status of the

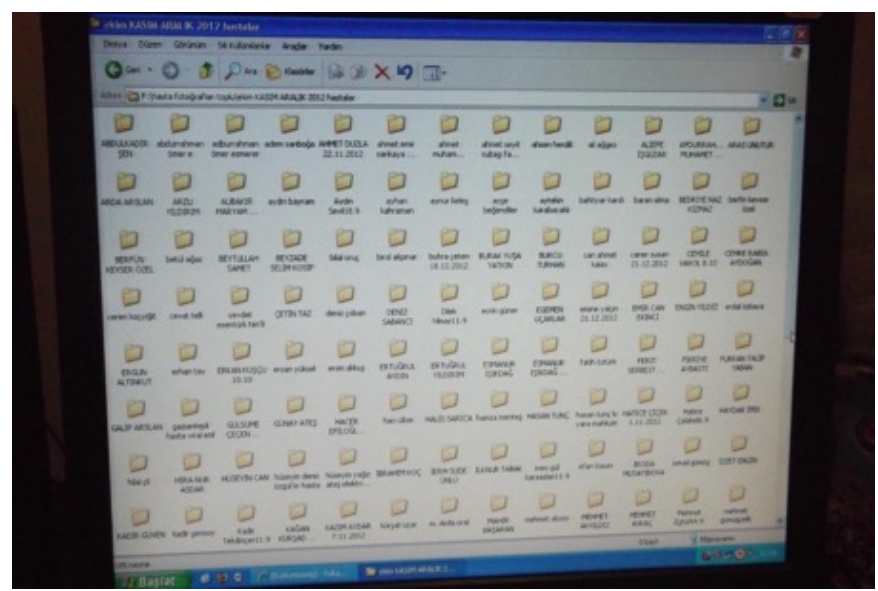

Figure 4. All images were collected at one base

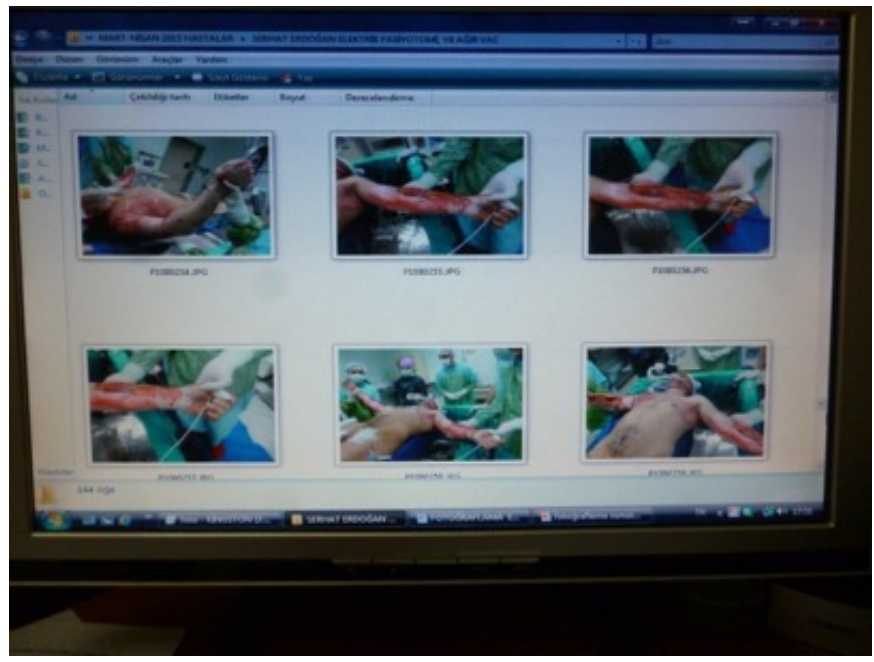

Figure 5. Photograph archives

grafts and the donor sites were also digitally recorded. When we mobilized the patients, we pictured the patient, and we put this image into the file.

During taking the photographs first a total body photo is received then, areas are considered separately (Figure 2). A barcode sticker that has the patient data is photographed right after imaging the patient. We collected all images at one base. Then the chief classifies the photos digitally according to name, time and location (Figure 3 ). All recordings were encrypted by password to prevent their improper use by other people (Figures 4 and 5). When the patient is discharged, the photographs are copied to a CD and placed in the patient's file. These CDs archived all data (Figure 6). We maintained the patient groups according to age, gender and the center where they are followed up. 


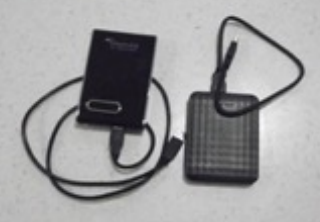

Figure 6. $C D$ or external hard disc archieves

Table 1. The distribution of the patients according to the gender and the center where they are followed up

\begin{tabular}{|c|c|c|c|c|c|}
\hline \multirow{2}{*}{} & \multicolumn{2}{|c|}{$\begin{array}{c}\text { The number of } \\
\text { adult patients }\end{array}$} & \multicolumn{2}{c|}{$\begin{array}{c}\text { The number of } \\
\text { children patients }\end{array}$} & \multirow{2}{*}{ TOTAL } \\
\cline { 2 - 5 } & Male & Female & Male & Female & \\
\hline $\begin{array}{c}\text { Burn Intensive } \\
\text { Care Unit }\end{array}$ & 358 & 251 & 126 & 104 & 841 \\
\hline Burn Service & 1167 & 832 & 356 & 258 & 2613 \\
\hline Outpatients & 3125 & 2840 & 1265 & 1175 & 8405 \\
\hline
\end{tabular}

Table 2. Distribution of the patients according to the burn percentage

\begin{tabular}{|c|c|c|c|c|c|c|}
\hline $\begin{array}{c}\text { BURN } \\
\text { PERCENTAGE (\%) }\end{array}$ & $\begin{array}{c}\text { BURN } \\
\text { SERVICE }\end{array}$ & \% & BICU & \% & TOTAL & $\%$ \\
\hline $\mathbf{0 . 1 - 9 . 9}$ & 1760 & 49.12 & 84 & 7.25 & 1844 & 38.89 \\
\hline $\mathbf{1 0 - 1 9 . 9}$ & 1322 & 36.88 & 160 & 13.79 & 1482 & 31.24 \\
\hline $\mathbf{2 0 - 2 9 . 9}$ & 343 & 9.58 & 177 & 15.22 & 520 & 10.96 \\
\hline $\mathbf{3 0 - 3 9 . 9}$ & 96 & 2.69 & 188 & 16.17 & 284 & 5.99 \\
\hline $\mathbf{4 0 - 4 9 . 9}$ & 55 & 1.54 & 195 & 16.77 & 250 & 5.26 \\
\hline $\mathbf{5 0 - 5 9 . 9}$ & 7 & 0.19 & 122 & 10.46 & 129 & 2.70 \\
\hline $\mathbf{6 0 - 6 9 . 9}$ & - & - & 83 & 7.14 & 83 & 1.74 \\
\hline $\mathbf{7 0 - 7 9 . 9}$ & - & - & 62 & 5.35 & 62 & 1.31 \\
\hline $\mathbf{8 0 - 8 9 . 9}$ & - & - & 44 & 3.81 & 44 & 0.93 \\
\hline $\mathbf{2 9 0}$ & - & - & 47 & 4.04 & 47 & 0.99 \\
\hline TOTAL & 3583 & 100.00 & 1162 & 100.0 & 4745 & 100.00 \\
\hline
\end{tabular}

\section{RESULTS}

As a result, during eight years between 2009 and 2017, we have collected pictures of 1162 burn intensive care unit patients, 3583 burn service patients, and 8405 polyclinic patients during every stage of their treatment (Table 1).

The highest rate of admission was in moderate burned patients was $49.12 \%$ ( $n$ : 1760) with a burned body surface area of $0.1-9.9 \%$, while in the severely burned group it was $16.77 \%$ (n: 195) with a burning body surface area of $40-$ 49.9\% (Table 2). The average percentage of burn surface area was calculated as $15.3 \%$. The burn percentage was significantly higher in the intensive care unit (35.2 $23.5 \%)$ compared to the burn service patients $(10.7 \pm 8.5 \%)(p<0.05)$.

When we examined the causes of moderate burns, the first order received scalding burns with $52.65 \%$ (n: 1886), and in severe injuries, it was flame burns with $54.22 \%$ (n: 630) incidence (Table 3).
Table 3. Distribution of the patients according to the burn etiology

\begin{tabular}{|c|c|c|c|c|c|c|}
\hline $\begin{array}{c}\text { BURN } \\
\text { ETIOLOGY }\end{array}$ & $\begin{array}{c}\text { BURN } \\
\text { SERVICE }\end{array}$ & $\%$ & BICU & $\%$ & TOTAL & $\%$ \\
\hline SCALDING & 1886 & 52.65 & 216 & 18.57 & 2102 & 44.29 \\
\hline FLAME & 1021 & 28.49 & 630 & 54.22 & 1651 & 34.82 \\
\hline ELECTRICAL & 179 & 4.99 & 242 & 20.81 & 421 & 8.86 \\
\hline CHEMICAL & 170 & 4.76 & 18 & 1.54 & 188 & 3.98 \\
\hline CONTACT & 167 & 4.65 & 17 & 1.43 & 184 & 3.87 \\
\hline OTHER & 160 & 4.46 & 39 & 3.33 & 199 & 4.18 \\
\hline TOTAL & 3583 & 100 & 1162 & 100 & 3441 & 100 \\
\hline
\end{tabular}

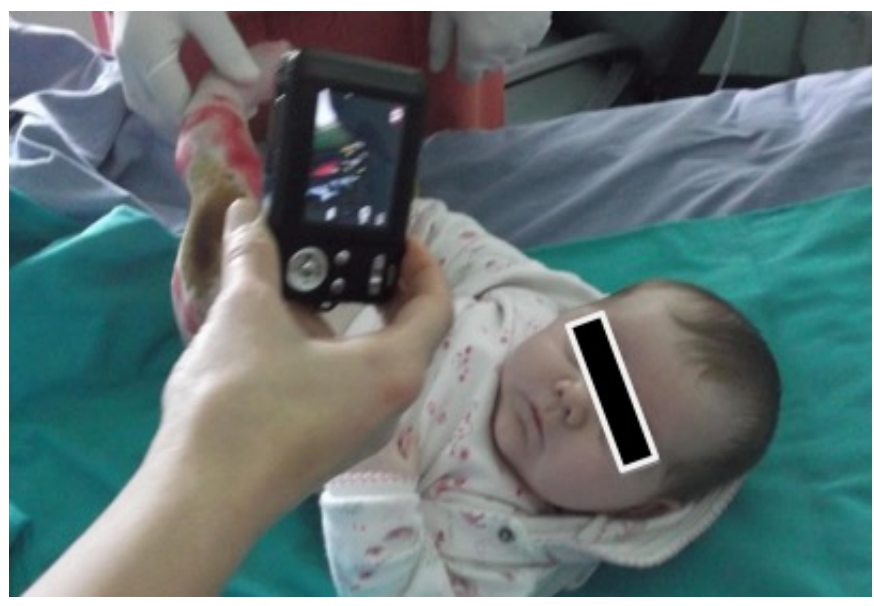

Figure 7. Every step of the treatment of our patients were recorded

We got the visual records of the patients,

a) We tried to record the status of the patients at the time of arrival or referral (Figure 7)

b) We worked on confirming the TBSA by the help of photographs,

c) We followed the treatment process by photos,

d) We consulted to other departments by sharing the images,

e) We traced our complications from the pictures and tried to improve ourselves,

f) We recorded the long-term esthetic results,

g) We used the data for education,

h) We used the information for legal situations and the clinical follow-up.

In 6 patients we used these images as evidence for burn percentage and depth in an investigation for us about the patient grievance. We used these images in inquiries about our treatment, and all of them were accepted as evidence and verified us.

\section{DISCUSSION}

Photographs of a burn injury provide an objective description of the patient's disease course and may be important in the medicolegal documentation of child abuse or other criminal and civil actions. Accurate and 
reproducible photographs require careful composition and choice of equipment. Standardized clinical positioning is described with recommendations for timing of following pictures [5].

Medical photographs are used to document medical conditions on individual patients, to teach and train the doctors, nurses, and technicians of tomorrow, and to promote the activities of hospitals and clinics to the public. They are also used as evidence in legal and criminal cases. Privacy laws and other constitutional limitations will govern Their use; to what extent depends on the country in which they are made [6].

Photographic documentation is an essential part of facial plastic surgery practice. Standardization of photographic technique is critical to achieving accurate and consistent images to be used for medicolegal, surgical planning, outcome review, research, and teaching purposes [7]. Constant, uniform, high-quality photography allows the best opportunity for critical self-assessment and selfeducation [8]. Digital imaging systems offer multiple advantages regarding quality, accessible image storage and retrieval $[9,10]$.

Boccara et al. [11] used medical photography to diagnose burn depth in patients, and they claimed that even though a detailed analysis cannot replace clinical examination, the comprehensive evaluation may be one option to consider for a first distance diagnosis. Shokrollahi et al. [12] investigated the accuracy of assessment of burn surface area and depth using a primary camera and a high correlation was found between appraisal of burn surface area and burn extent utilizing a camera compared with a live assessment.

Hardwicke et al. [13] reported a photographic archive had been discovered that documents this period from 1945 to1975. It is a unique resource that records the scientific approach to the management of burns and accompanies the contemporary literature of the day.

Photography became a part of treatment in burn patients. These photographic images can determine the calculation of the burn percentages, evaluation of the injuries at first admission, the definition of the infected regions or the elements which will be grafted. Also, finding the reasons for graft loss, following the wound healing and the sequela can be performed by these photographs. They can also be evidence of the treatment and the materials used.

Medical photography is gaining importance as time goes on with the developments in medicine and increasing legal responsibilities of the healthcare workers. In malpractice courts, photographic recordings can be essential evidence for these workers elucidating every phase of the treatment [14]. Clinicians might not always have available the services of a professional medical photographer, but if a standardized approach is followed those who take their clinical photographs can achieve acceptable results.

We think that if this photographic recording of our patients continues, many essential and strange studies can be directed to the collected data in future. In the future, we want to improve photo quality and attend a medical photography training as a team. We plan to start making videos, to be able to use database programs that calculate burn surface area. Storing both the patient file and images electronically is also essential. A professional medical photographer and medical secretaries who will keep all these records may improve the quality of the collected data.

We also think that for countries like us who believe devices like laser Doppler imaging and photoacoustic imaging are expensive, digital photography can be a cheap and straightforward way for recording the images of burn patients.

\section{DECLARATION OF CONFLICT OF INTEREST}

The authors declare no conflict of interest

\section{REFERENCES}

1. Glasser O. The first roentgen photograph (Mrs. Roentgen's hand.) In: Wilhelm Conrad Röntgen and the early history of the Roentgen rays, 1933, London: Bale \& Danielsson, p. 130.

2. Hop MJ, Stekelenburg CM, Hiddingh J, Kuipers HC, Middelkoop E, Nieuwenhuis MK, Polinder S, van Baar ME; LDI Study Group. Cost- Effectiveness of Laser Doppler Imaging in Burn Care in The Netherlands: A Randomized Controlled Trial. Plast Reconstr Surg 2016; 137:166e-76e.

3. Menon S, Ward D, Harvey JG, Hei EL, Holland AJ. Friction burns in children: does laser Doppler imaging have a role? J Burn Care Res 2012; 33:736-40.

4. DiBernardo BE, Adams RL, Krause J, Fiorillo MA, Gheradini G. Photographic standards in plastic surgery. Plast Reconstr Surg 1998; 102(2):559-568.

5. Smoot EC 3rd, Higgs J. Photographing the patient with burns for medical documentation. J Burn Care Rehabil 1994;15:434-7. 
6. Lakdawala N, Fontanella D, Grant-Kels JM. Ethical considerations in dermatologic photography. Clinics in Dermatol 2012; 30:486-91.

7. Khavkin J, Ellis DA. Standardized photography for skin surface. Anat Sci Educ 2011; 4:348-56.

8. Becker DG, Tardy ME Jr. Standardized photography in facial plastic surgery: pearls and pitfalls. Facial Plast Surg 1999; 15:93-9.

9. Persichetti P, Simone P, Langella M, Marangi GF, Carusi C. Digital photography in plastic surgery: how to achieve reasonable standardization outside a photographic studio. Aesthetic Plast Surg 2007; 28:194-200.
10. Archibald DJ, Carlson ML, Friedman O. Pitfalls of nonstandardized photography. Facial Plast Surg Clin North Am 2011; 19:241-6.

11. Boccara D, Chaouat M, Uzan C, Lachere A', Mimoun M. Retrospective analysis of photographic evaluation of burn depth. Burns 2011; 37:69-73.

12. Shokrollahi K, Sayed M, Dickson, Potokar T. Mobile phones for the assessment of burns: we have the technology. Emerg Med J 2007; 24:753-5.

13. Hardwicke J, Kohlhardt A, Moiemen N. The Birmingham Burn Centre archive: A photographic history of post-war burn care in the United Kingdom. Burns 2015; 41: 680-8.

14. Nayler JR. Clinical Photography: A Guide for the Clinician. J Postgrad Med 2003; 49:256-62. 